\title{
THE FINNISH LOGOPHORIC PRONOUN HÄN: A QUANTITATIVE APPROACH
}

\author{
Katri Priiki \\ University of Turku
}

\begin{abstract}
The paper examines the logophoric use of hän 'he/she' in contemporary Finnish conversation data. A logophoric pronoun is a device used in reported speech referring to the original speaker of a reported utterance. In informal spoken Finnish the pronoun hän is mostly used logophorically, even though in Standard Finnish, it is the regular third person personal pronoun. The paper approaches the logophoric function of hän from a new, quantitative viewpoint by examining the frequency of different aspects of the logophora. Based on the quantitative analysis of the data, the canonical construction of indirect speech seems to be the most typical context for the pronoun hän to occur, even though previous studies have claimed Finnish logophora semantic rather than structural. From the prototypical position the logophoric use spreads to reporting thoughts, interpreting feelings, and expressing the roles of the participants of the interaction.
\end{abstract}

Keywords: logophora, personal pronouns, pronouns, reported speech, spoken language, third person, Finnish

DOI: https://doi.org/10.12697/jeful.2017.8.2.011

\section{Introduction}

A logophoric pronoun is a device used in reported speech referring to the original speaker of a reported utterance (e.g. Culy 1997). This article examines the Finnish third person pronoun hän ('he/she') as a logophoric pronoun in contemporary spoken language. In the most recent comprehensive grammar of Finnish (ISK), this pronoun is defined as a personal pronoun, and in Standard Finnish the proper way to refer to human beings is to use hän. However, in informal spoken language and in most Finnish dialects, referents in the third person, including people, are mostly referred to with the anaphoric demonstrative pronoun se ('it, he/she'). In contrast to se, colloquial hän is used as a logophoric pronoun. (ISK, §1469.) 
Earlier research on old Finnish dialect data presents examples of clauses in which the third person pronoun changes: in indirect reported speech, when referring to the subject of the reporting clause, the third person pronoun is always the logophoric pronoun hän and never the anaphoric demonstrative se (Setälä 1883: 85; Saukkonen 1967: 286; Kallio 1978: 66-67). Occurring in the context of a clause (1) $)^{1}$, for example, se would signal a reference to another person (cf. Setälä 1883: 85). However, in modern conversation data, this may no longer be the case. That is, the logophoric use of $h \ddot{a} n$ is inconstant in the sense that using the demonstrative se in a logophoric context (2) does not result in misunderstanding, neither does using hän outside a structurally logophoric context (3).

$\begin{array}{lllllll}\text { (1) Se sano-i, että hän anta-a } & \text { ne } & \text { minu-lle } \\ \text { DEM Say-PST that HÄN } & \text { give-3SG } & \text { DEM.PL } & \text { 1SG-ALL }\end{array}$

$\mathrm{He} / \mathrm{she}_{1}$ said that he/she $\mathrm{s}_{1}$ gives them to me

(2) mut se-hän se-hän sano et se on tosi

but DEM-CLTC DEM-CLTC say.PST that DEM be.3SG really

ujo: ja se-mmone

shy and DEM-ADJ

But he $_{1}$ said that he $e_{1}$ is really shy and like that

$\begin{array}{llllll}\text { (3) no (.) } & \text { pysty-ks } & \text { hän (.) } \ddot{a} \text { - (.) } & \text { saa-ks } & \text { hä } & \text { auto-o ajja-a } \\ \text { well } & \text { be.able-Q } & \text { HÄN } & \text { be.allowed-Q } & \text { HÄN } & \text { car-PTV drive-INF }\end{array}$

Well, is she able- is she allowed to drive a car?

The research on the logophoric function of the pronoun hän (Laitinen 2005 and 2002, and Nau 2006) has concentrated on data from old dialect interviews. As has been shown above (2-3), the logophoricity of the Finnish hän in contemporary language may not be as constant as it is claimed by Setälä (1883), Saukkonen (1967) and Kallio (1978) to have been. Added to this, the focus of research has been on categorical phenomena and whether they are possible or impossible in the language; the question of what is frequent or infrequent has thus been neglected. In this article, I focus on modern colloquial conversations and quantitative analysis: What can frequency tell us about the phenomenon called logophora in current Finnish usage?

1 Example (1) is from the comprehensive grammar of Finnish (ISK, §1469). 
In different Finnish regional dialects, the pronoun hän has also been used more or less frequently outside the canonical logophoric context, as in example (3) above. In this article, I explore how many of the occurrences not structurally logophoric may be explained by semantic logophora in a modern regional dialect, the speech of 21th century Satakunta. As I stated above, in contemporary spoken Finnish hän is not obligatory in the logophoric position and the variation between hän and se does not create misunderstanding. Should we then still call hän a logophoric pronoun? What is the primary function of hän in this regional dialect today? Is it possible to measure grammaticalization (or ungrammaticalization) by measuring frequency?

In the next section, I will introduce the notion of logophora in Finnish and other languages. The results are presented in Section 3 and the findings are discussed in Section 4.

\section{Logophora and the Finnish third-person pronoun system}

Logophoric pronouns have developed to solve a particular problem in direct and indirect quoting. The problem is that, on the one hand, quoted utterance containing first and second person pronouns may be misinterpreted as referring to the actual speaker and addressee, while on the other hand, in indirect quoting the third-person pronoun may be ambiguous with a reference to someone who is not a participant of the reported speech situation. The origin of logophoric pronouns is in the first or third person elements and in some cases in reflexive pronouns. In languages where the logophora is the primary function of a pronoun, the marking of coreference in reported speech is unambiguous and obligatory, that is, grammaticalized. However, grammaticalization is often a matter of degree. (Bhat 2004: 58-69.)

In addition to reporting speech with the canonical indirect speech construction, it is possible to use logophoric pronouns when interpreting another person's thoughts, feelings, perceptions, and when expressing their viewpoint in conversation. When logophora is understood in a wide sense, reporting all second hand knowledge may be expressed using logophoric devices (Bhat 2004: 58). When defined strictly, logophoric use may be limited to the canonical constructions of reported speech (Hyman and Comrie 1981). Genuine logophoric pronouns are obligatory in the context where they belong in that specific language, but languages differ as to what kind of a predicate of the introductory phrase triggers the logophora in the canonical construction (Bhat 2004: 
72, and Culy 1997). An agent is more likely to trigger logophora than an experiencer (Roncador 2006: 313). Stirling (1993: 259 and 1994: 2304) presents a hierarchy of predicates as the following:

communication $>$ thought $>$ psychological state $>$ perception

If a logophoric pronoun is used with one type of predicate, it is also used with predicates to the left of it on the scale. For example, if a logophoric pronoun occurs with verbs that express a psychological state, it also occurs with verbs of thought and communication. I will use this hierarchy as a starting point in exploring the frequency of the Finnish logophoric pronoun hän in different contexts in section 3 .

Logophora, as a phenomenon, is documented in many languages in West and Central Africa and its proper form is claimed to be restricted to this area (Roncador 2006: 314). However, Nicole Nau (2006) shows that pronouns used in indirect speech in both Finnish and Latvian dialects share many features with logophoric elements in African languages. Laitinen (2005: 82) presents evidence that in eastern Finnish hän has been logophoric for at least four or five hundred years. Among the languages related to Finnish, Saami languages have an equivalent logophoric pronoun sun/son (Nickel 1994: 96-100, 119). In Estonian, Votic, and Livonian the etymologically corresponding pronouns are reflexive (Laitinen 2002). The Finnish hän also is thought to have been a reflexive pronoun, and examples of the reflexive use of $h \ddot{a} n$ are found in old dialects (Laitinen 2002, and SMS, s.v. hän). Example (4) is from a rural dialect, spoken in the late 19th and early 20th century in Halikko in South-Western Finland (SMS, s.v. hän).

\section{(4)

$\begin{array}{lllll}\text { Jop } & \text { istu-s } & \text { tuhva-s ja } & \text { kraape } & \text { hän-tä-s } \\ \text { name } & \text { sit-PST } & \text { ash-INE and } & \text { scratch.PST } & \text { HÄN-PTV-3SG.POSS }\end{array}$

Jop sat in the ashes and scratched himself

In the comprehensive grammar of Finnish (ISK), the logophora is defined structurally: a logophoric pronoun occurs in reported speech, preceded by an introductory phrase expressing the original speaker and describing the speech act. In reported speech the logophoric hän refers to the subject of a speech act verb in the introductory phrase, as in example (1) above. (ISK, §1469.) Besides the indirect speech construction, the Finnish hän is described to occur also in those main clauses interpreting another person's feelings and viewpoint (Laitinen 2002, and Siitonen 2008). The logophoric function of hän has also evolved 
further so that hän may express evidentiality, uncertainty, and deprecation (Laitinen 2005).

Based on the fact that the logophoric hän is not restricted to the canonical construction, Laitinen (2005) and Nau (2006) suggest that hän is a genuine logophoric pronoun similar to corresponding pronouns in the High Latvian dialect and in many African languages. Thus its main function would be to semantically distinguish the participants of a reported speech situation from the actual speaker and addressee (cf. Roncador 2006), not just to occur as a part of the syntactic structure of the indirect speech construction, as it is defined in Finnish grammar (ISK, §1469).

In modern Finnish, the logophora is, however, only one of the factors controlling the use of hän in spoken interaction. There are at least two other factors: regional dialect and the written standard language. The data for this study consists of audio-recorded conversations from the transition dialect area in south-western Finland. In old dialect interviews from this area, $h \ddot{a} n$ has been used relatively frequently as a neutral third person pronoun (cf. Siitonen 2008), and even in the recent data (recorded between 2009 and 2011) the structurally prototypical logophoric context explains only one third of the occurrences of $h \ddot{a} n$. Added to this, the norm created in Standard Finnish, following the exemplar of many European languages and thought to eliminate irregular variation, instructs that hän should refer to people and se only to animals and inanimate objects.

Based on folk linguistic surveys (Priiki 2011 and 2016a, and Siitonen 2008: 104), speakers are very well aware that in spoken and written language a different third person pronoun is used. Due to the Standard Finnish norm, many speakers think hän would also be a more polite choice in spoken language. For instance, the standard-language use of $h \ddot{a} n$ is more common in institutional situations (Lappalainen 2010, and Nuolijärvi 1986: 290-300), and when speaking with an unfamiliar person (Priiki 2016a). On the other hand, the extensive use of $h \ddot{a} n$ in written language has also caused some people, especially the young, to consider it too formal for casual conversations. Even though they think that using hän when referring to people is in fact "better" language, they find the pronoun unnatural and constrained (Priiki 2016a; Siitonen 2008: 104). Therefore, they may avoid $h a ̈ n$ in general, even in logophoric contexts. 


\section{Logophoric hän in the data}

The data consist of 24 hours of multi-party conversations recorded in five small towns, in the province of Satakunta in south-western Finland, where south-western transition dialects are spoken. The transition dialects are a dialect group sharing features from two surrounding main dialects. In the recordings, 33 speakers produce 2833 occurrences of the singular pronouns hän and se in reference to people not present in the speech situation. In this section, I will classify the occurrences according to which kind of logophora (if any) they express, and calculate the percentages of hän and se. I will also discuss how the proportion of hän corresponds to Stirling's hierarchy of logophoric contexts presented in Section 2.

\subsection{Reported speech or mental process}

In studies of Finnish grammar, the means of expressing reported speech have been classified according to structure. Added to direct and indirect quoting, the Finnish language also has other ways to convey second hand knowledge (Kuiri 1984). In spoken language, mixed quotes, in which only some of the elements change, are frequent. More abstract means convey only the content of the original utterance thus the current speaker's interpretation increases. According to Kuiri (1984), the abstract ways of reporting speech are infrequent in spoken discourse.

I have counted all canonical indirect or mixed quoting constructions where the reported utterance includes a third-person pronoun that is coreferential with the subject of the reporting clause. The indirect quotes regularly use conjunction että 'that', usually shortened to $e t$. I have also collected all similar constructions that convey the referent's thoughts or feelings (5 and 6).

(5) se luul-i et hän-en täytyy yksinääm puhu-a DEM think-PST that HÄN-GEN must alone speak-INF

$\mathrm{He}_{1}$ thought that he 1 would have to speak alone 


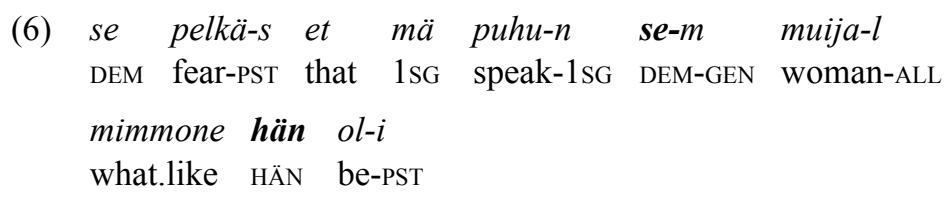

$\mathrm{He}_{1}$ was afraid that I would tell his 1 wife how he behaved $_{1}$

The first observation is that relating another person's mental processes with a similar construction to reported speech is quite rare in conversational data. Compared with 171 indirect or mixed speech constructions, there are only nine occurrences of a construction consisting of an introductory phrase expressing a mental process, the conjunction että 'that', and a reported thought including a third-person reference to the subject of the reporting clause. As in example (5), the reporting clauses mostly express cognition. In the reported part, the logophoric pronoun hän is used seven times, the demonstrative se two times. There is only one occurrence of this construction with an emotion verb, pelätä 'fear', presented as example (6). It is a complex construction, consisting of not only two, but three, layers. In example (6), the reported utterance includes both pronouns se and hän. They are coreferential, and the choice between se and hän does not follow the logic of a prototypical logophoric construction: the first reference in the reported part is a reference to the subject of the matrix clause but the pronoun is $s e$, and in the second reported part the pronoun hän does not refer to the subject of the adjacent matrix clause ('I would tell') but the previous one ('He was afraid').

The ways of conveying another person's emotion in conversational speech seem to be somewhat different than when quoting speech or thoughts. Instead of relating the content of an emotional reaction, a speaker quite often reports its cause, as in example (7). This is done with the causal conjunction kun (colloquial variants $k u / k o$ ), but other parts of the construction are quite similar to the examples shown above and interestingly, the pronoun hän is used (cf. also Laitinen 2005: 90). Researchers with observations from old dialect interviews, especially in the dialects of Satakunta, claim that the pronoun hän is widely used in kun-clauses (SMS, s.v. hän).

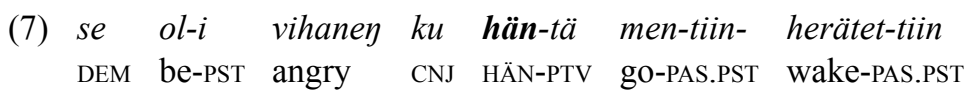

She $_{1}$ was angry because she $e_{1}$ was awakened 
The data includes 11 cases resembling (7), where the subordinate clause expressing a causal connection uses a third-person pronoun when referring to the subject, i.e. the thinker or the experiencer of the main clause. The conjunction kun in colloquial Finnish is a sort of a generic conjunction having a wide distribution of functions (Ikola et al. 1989: 89-93). The main function of the conjunction kun is temporal (ISK, $\S 1122$ ), but in southwestern dialects, it is also observed to have an explicative function; in which case, it would be possible to use it instead of the regular explicative conjunction että (Ikola et al. 1989: 89-93). According to my interpretation though, in the cases found in my data the relation expressed with the conjunction kun is causal: the latter part is the reason why the person mentioned in the main clause is feeling or thinking the way he or she does (cf. Herlin 1998: 106-108). Interestingly, using $h \ddot{a} n$ in example (7) excludes the temporal interpretation of the kun-clause ('she was angry when she was awakened'), which could be possible if se were used.

The cognitive processes conveyed with the causal construction shown in (7) are in this data usually feelings. Even though the constructions with different conjunctions do not fully correspond, it is interesting to see that the logophoric pronoun hän is equally frequent in both. A more detailed study of the frequency of hän in kun-clauses in contemporary speech, and its relation to logophoric use, would need a larger data set.

I have classified the utterances in the data according to whether they convey another speaker's speech or a mental process. Then I have calculated how many of the cases utilize the logophoric pronoun hän, and how many the anaphoric pronoun se. I also included in the comparison the kun-clauses mentioned above, in order to show how similar the variation between these two pronouns is when compared with the quoting of mental processes with the ettë-construction. The cross tabulation is presented in Table 1. To evaluate the strength and significance of the correlations found, I used adjusted standardized residuals. Residuals express the difference between the expected count and the observed count. The correlation is thought to be significant if the absolute value of the standardized residual is greater than two. (Agresti 2002: 80-81.)

The percentages show that when there is no prototypic logophora, the majority of the pronouns used in the data are occurrences of the anaphoric demonstrative pronoun se (86\%, residual 26.9). In the logophoric position quoting speech, the pronoun is almost categorically hän $(97 \%)$. However, there are six occurrences of se in clearly logophoric contexts, but none of them cause any problems for the hearers to inter- 
pret who the referent is. These occurrences of se in logophoric contexts are produced by speakers who use hän very rarely in general. These speakers are generally young or middle-aged. As mentioned above, some of the young people in the Satakunta area think that hän only belongs to institutional situations and written language and it may be too formal in colloquial speech. These people may consciously avoid using hän even in logophoric contexts. (Priiki 2016b.)

Table 1. Frequency of hän in logophoric contexts quoting speech and thought. (Fisher's Exact Test $\chi^{2}=569.1 ; p<0.001$.)

\begin{tabular}{l|c|c|c|c|c} 
& $\begin{array}{c}\text { No } \\
\text { structural } \\
\text { logophora }\end{array}$ & $\begin{array}{c}\text { Quoting } \\
\text { speech }\end{array}$ & $\begin{array}{c}\text { Quoting } \\
\text { mental } \\
\text { process } \\
(\text { että })\end{array}$ & $\begin{array}{c}\text { Interpreting } \\
\text { the cause of } \\
\text { mental } \\
\text { process }(k u n)\end{array}$ & All \\
\hline hän & 370 & 165 & 7 & 7 & 549 \\
$\%$ & $14 \%$ & $97 \%$ & $78 \%$ & $64 \%$ & $19 \%$ \\
Adjusted residual & -26.9 & 26.3 & 4.4 & 3.7 & 2284 \\
\hline se & 2272 & 6 & 2 & 4 & $81 \%$ \\
$\%$ & $86 \%$ & $4 \%$ & $22 \%$ & $36 \%$ & -3.7 \\
Adjusted residual & 26.9 & -26.3 & -4.4 & 11 & 2833
\end{tabular}

In Table 1, a highly significant positive correlation (residual 26.3) can be seen between pronoun hän and the indirect quoting of speech. Even though the number of cases is low, there is also a significant correlation between hän and quoting mental processes (residual 4.4), but the connection is clearly weaker than when quoting speech. Cross tabulation shows that quoting mental processes with an että-clause and interpreting the cause of mental processes with a kun-clause do not differ in the distribution of hän. The percentages of both contexts as regards hän are closer to quoting speech than cases with no structural logophora. However, the number of cases quoting mental processes is so low that the results may not be reliable.

The pattern in the frequency of the pronoun hän can be interpreted as reflecting the continuum presented by Stirling (1993: 259 and 1994: 2304) as mentioned previously, where quoting speech is the primary context of logophoric elements and conveying someone else's mental processes is seen as an extension of this function. In spoken Finnish, the logophoric pronoun hän is the most common, although not a categorical choice, in prototypical indirect quotes. It is also used when quoting the 
referent's thoughts (and perhaps feelings) with a similar construction, but this structure seems quite rare in everyday conversation. A similar structure describing the referent's perception (e.g. she, heard that they were talking about her $r_{1}$ ) is even more marginal: there are no examples of such cases in the data. Even though quoting someone's speech using a reporting clause, a quoted utterance (and often a logophoric $h \ddot{a} n$ ) is quite a common phenomenon; relating what a third person is or was thinking or feeling is mostly done by different means. As Nau (2006: 66) proposes, the logophoric hän may be used without a report opener, and in the following I will examine this kind of occurrences.

\subsection{Interpreting referent}

In the previous section, I showed that in conversational speech the prototypical syntactic logophoric construction is quite rare when the referent's thoughts are quoted and marginal when the referent's feelings and perceptions are concerned. How then are another person's thoughts and feelings transmitted? Laitinen (2002) and Ylikahri (1996) show examples of the Finnish hän being used to indicate the referent's point of view and interpreting their mental processes without the prototypical construction, as in $(8)^{2}$.

(8) No mitä-s $\quad$ häa pelkä-is!
Well what.PTV-CLI HÄN be.afraid.3sG-CON
Well, what would s/he be afraid of!

It is suggested that the logophoric function of $h a ̈ n$ might be broadened into referring to a participant in a speech situation in main clauses, e.g. the reporting clauses (Ylikahri 1996). If this is applicable to the modern data studied in this article, it is to be expected that, added to the prototypically logophoric use in indirect speech reports, pronoun hän would also be more frequent as a subject of a speech act verb than in other contexts in the data. If hän is commonly used when interpreting the referent's mental processes or indicating the referent's point of view in main clauses, as in example (8), it would be more frequent as a subject of verbs expressing cognition, emotion, and perception. In the following analysis, I have confined the examination to pronouns occurring as a

2 Example (8) is from Laitinen (2002: 333). 
subject. I have classified the predicates semantically as speech acts, cognition, emotion, and perception. The rest are grouped in other verbs.

Speech act verbs describe any acts of producing oral communication, including the verb olla 'be' when it is used in a reporting clause ${ }^{3}$, as in example (9). In the data there are 323 occurrences of speech act verbs with the pronoun hän or se as the subject. The majority of speech act verbs are occurrences of the two most frequent, general speech verb lexemes sanoa 'say' (185 cases) and puhua 'speak, talk' (38 cases).

(9) sit se ol-i et @joojoo@
then DEM be-PST that yeah yeah

Then she was like "yeah yeah"

Verbs of cognition include the verbs of thinking, knowing, and understanding. In addition, modal verbs describing psychological ability, like 'dare' and 'know how', have been encoded as cognition verbs. Cognition verbs are less frequent in the data than speech act verbs but more frequent than emotion or perception verbs - there are 127 occurrences. The most frequent of them in the data are tietää 'know' (11 cases), osata 'know how' (10 cases), and meinata 'aim, plan, think' ( 8 cases).

Emotion verbs convey information about how someone feels about a person, an object or an event, such as 'love' or 'hate'. There are 47 occurrences of emotion verbs with the pronoun hän or se as a subject referring to a person. A number of emotion verbs may be classified as desiderative, such as 'want' and 'wish'. In the data, there is only one verb lexeme, haluta 'want' (10 occurrences) that could be classified as desiderative, and I have grouped it together with emotion verbs. Other frequent emotion verbs in the data are tykätä 'like' (11 cases) and pelätä 'be afraid, fear' ( 8 cases). Verbs of perception include the verbs of hearing, seeing, tasting, and smelling. There are 42 occurrences of perception verbs in the data, and the most frequent lexemes among them are nähd̈̈ 'see' (13 cases), and katsoa 'look' (12 cases).

Table 2 presents a cross tabulation of the pronouns hän and se, used as subjects referring to a human being, and their predicate verbs, according to whether they express speech act, cognition, emotion, or perception. As in Table 1 above, the adjusted standardized residuals describe the strength and direction of the correlations.

3 More about this kind of use in English cf. Tagliamonte 2009. Finnish use of olla 'be' as a speech act verb is a recent loan from English. 
The correlations in Table 2 are not as strong as in Table 1, but a quite clear picture can be seen. The strongest correlation (residual 5.0) is between the pronoun hän and predicates expressing cognition, like in example (10). Additionally, emotion verbs, as example (11), include a hän-subject significantly more often than other predicates. Perception verbs do not differ significantly from verbs encoded as "other". Here the frequency of hän-subjects with cognition, emotion, and perception verbs may be seen as complying with the continuum presented by Stirling (1993: 259 and 1994: 2304). The logophoric pronoun hän in Finnish is extended to the main clauses interpreting the referent's thoughts and feelings, but not perception.

Table 2. Pronouns hän and se as subjects of different predicate verbs. (Pearson $\chi^{2}=42.9 ; p<0.001$.)

\begin{tabular}{l|c|c|c|c|c|c} 
& Cognition & Emotion & $\begin{array}{c}\text { Per- } \\
\text { ception }\end{array}$ & $\begin{array}{c}\text { Speech } \\
\text { act }\end{array}$ & Other & All \\
\hline hän & 47 & 15 & 10 & 37 & 290 & 399 \\
$\%$ & $37 \%$ & $32 \%$ & $25 \%$ & $12 \%$ & $20 \%$ & $20 \%$ \\
Adjusted residual & 5.0 & 2.1 & 0.8 & -4.1 & -0.3 & \\
\hline se & 80 & 32 & 30 & 286 & 1186 & 1614 \\
$\%$ & $63 \%$ & $68 \%$ & $75 \%$ & $89 \%$ & $80 \%$ & $80 \%$ \\
Adjusted residual & -5.0 & -2.1 & -0.8 & 4.1 & 0.3 & \\
\hline All & 127 & 47 & 40 & 323 & 1476 & 2013
\end{tabular}

(10) se-mmone (.) Emma johon joyka tapa-si-n tual DEM-ADJ NAME who.ILL who.gen meet-PST-1SG there Pohjo(i)s-Norja-ssa. puhu (.) puhu suome-a (.) mut North-Norway-INE speak.PST speak.PST Finnish-PTV but ei hän_ossa-a luke-e ei-kä kirjotta-a NEG HÄN can-3SG read-INF NEG-CLI write-INF

This Emma, whom I met up there in northern Norway, she spoke Finnish but she can't read or write it.

(11) ei hän sillon tul-lus sitten su-n juhl-iiy-ka. neg HÄN then come-PCP then 2SG-GEN party-INE-CLI

ei hän tykän-nyt tull-as sinnek-kä.

NEG HÄN like-PCP come-INF there-CLI

He didn't come to your party then. He didn't like to come there either. 
Interestingly, the view of hän referring to someone described speaking in a main clause lacks quantitative support: the percentage of $h \ddot{a} n$-subjects of speech act verbs is actually significantly lower $(12 \%$, adjusted standardized residual -4.1$)$ than on average in the data (20\%). A previous study shows that in conversational data third person predicates referring to people are more often speech act verbs, while in first and second person cognition verbs and emotion verbs are more frequent, and the most frequent lexemes also are different in first and second person compared with third person (Priiki 2014). This may be the reason why discussing someone, who is not present in the speech situation, it is more usual to relate observations about what they have said rather than explain what the speaker thinks they have thought or felt.

Similar logic may also explain why the logophoric pronoun $h a ̈ n$ is more common with cognition and emotion verbs but less common with speech act verbs. A previous study notes the usage of hän in reporting clauses and in references to a participant of a speech act, and describes this as an expansion of the logophoric function (Ylikahri 1996). However, at least in this conversational data from the southwestern transition dialect, these observations do not attain quantitative support. The results shown above support the observations made by Seppänen (1998) and Siitonen (2008) that the pronoun hän is used in interpreting the referent's mental processes and showing the viewpoint of the referent. If the speaker relates what another person said, the utterance may be formed totally from the speaker's own viewpoint describing his or her perception. In contrast, when another person's thoughts or feelings are discussed, it demands taking the viewpoint of the referent and making assumptions about their mental processes. The quantitative results of the usage of the Finnish logophoric hän support the notion that empathizing and interpreting may be more logical directions where the logophoric function is extended rather than the references to the original speaker in reporting clauses.

When the analysis of the data is continued with qualitative analysis, it is possible to see that changing viewpoints may explain the variation between hän and se even more widely than just with different predicate verbs. In the next section, I will examine this phenomenon. 


\subsection{Semantic logophora and second hand information}

In addition to interpretation with the verbs of cognition and emotion, which I have discussed previously, the Finnish logophoric pronoun may also express the viewpoint of the referent in other kinds of clauses (Vilppula 1989: 396). These kind of occurrences are difficult, maybe impossible, to count reliably and compare with the occurrences of se, because sometimes the pronoun hän is the only means to create the impression of someone else's voice other than the speaker's own (cf. Nau 2006: 66). However, this function of hän seems quite typical, especially in narratives: a speaker who tells an emotional and fascinating story may act out a dialogue between characters in the story without using any reporting clauses. The presented dialogue is often mostly direct quotes. However, utterances where the reported speaker would have used first person forms, usually include the logophoric third person pronoun hän. This way of using hän is also noted by Laitinen (2005: 86-86). An example of this kind of narrative is presented in (12), where a middle-aged woman talks about an encounter with a poisonous snake on the doorstep of her garage: She asked her father to come and kill the snake, but he was busy. In the excerpt ${ }^{4}$, she acts out the phone conversation between herself and her father. In this case, the pronoun hän in a formally independent clause creates an impression of reported speech.

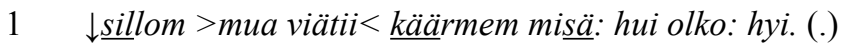

Then I got nervous. "A snake, where, yikes, yack." [A co-participant laughs quietly.]

2 meij jäi (.) auto saaminey ku se meni tosa just sit (.) sit mää soitim mei (.) We couldn't get our car out because it was right there. Then I called our

3 isä:l (.) pappal (.) et nyt äkkii tappamaan tääl_on käärme. (.) ja toi noin dad, grandpa, that "Now hurry to kill. There is a snake here". And

4 ni. (.) no ei hän ny- mitä-s pappa-l sit ol-i well. well NEG HÄN now what-CLI grandad-ALL then be-PST

(He said) "Well I can’t right now-“. What was it? Grandpa was

4 In the long examples I have only glossed the rows where the examined pronouns occur. 


jottain teke:-mi-st. se juur tul- syä-miney keskev
something do-INF-PTV DEM just come eat-INF in.the.making
vai m-mikä:
or what

in the middle of something. He just came- He was just eating

$\begin{array}{lllllllll}6 & \text { se-nn_- } & \text { ol-i. } & \text { kyl } & \text { hän } & \text { täält } & \text { sit tull-ee } & >\text { mää } & \text { sano-i< } \\ & \text { DEM-GEN } & \text { be-PST yes } & \text { HÄN } & \text { from.here then come-3SG } 1 \mathrm{SG} & \text { say-PST }\end{array}$ or something. (He said) "I will come (from here) in a while". I said

The reconstruction of the phone call begins with a reporting clause ('then I called our dad (.) grandpa that') and a direct quote of the speaker's own utterance. The father's hesitating answer (no ei hän ny-, row 4 ) is presented without a reporting clause. A discourse particle no 'well' and the word $n y$ 'now' referring to the original speech situation give an impression of a direct quote. Instead of a first person pronoun, hän is used. Then the speaker shifts from the phone conversation to explaining the next part of the story: her father had something else to do and he could not come right away to kill the snake. In this part, the speaker refers to her father with the anaphoric demonstrative pronoun se (rows 5 and 6). At the end of the excerpt (row 6) there is another shift back to the phone call. The father promises to come when he can, and this is presented again with a mixed quote without a reporting clause: a discourse particle, the deictic täält 'from here' referring to the father's place, and the present tense belong to a direct quote, but instead of the original first person the speaker uses hän.

It is possible that the conversation reported in example (12) might resemble the actual way in which they occurred in the story. The logophoric pronoun hän, however, may also occur in contexts where there is no actual previous conversation to report. Instead of quoting actual utterances, another voice can be heard in the story, bringing someone else's thoughts and opinions to it - or just a shade of second-hand knowledge. This is a clue that the incident described has not been witnessed by the speaker, but has been told to the speaker by the person referred to by the pronoun hän. This is the case in excerpt (13). A tells $\mathrm{B}$ about an acquaintance whose rheumatism was miraculously cured. The acquaintance, Tarja, is repeatedly referred to with the pronoun hän. 
Contrasting to this, another referent in the story, a doctor, is referred to with the pronoun se (row 5).

1 A: ja Tarja lopetti [lääkkeen_ottamisen,(.)

And Tarja discontinued taking medicine

$2 \mathrm{~B}$ :

$$
\begin{aligned}
& {[\text { nii? joo? }} \\
& \text { Yeah okay }
\end{aligned}
$$

$3 \mathrm{~A}: \quad j a($.$) ei mittään_olt tul-lu \quad j a() \quad k y$.$l hän$ and NEG anything_be come-PCP and yes HÄN

lääkäri-l(les) se-n sano,

doctor-ALL it-GEN say.PST

and no symptoms came back and of course she told the doctor about it

4 B: nii?

Yeah

$5 \mathrm{~A}$ : jälkkeempäij ja(.) sano et ei se siihem afterwards and say.PST that NEG DEM it.ILL

mittään sano-nu.

anything say-PCP

later and said that s/he (the doctor) didn't say anything

6 B: (joo).

Yeah

$7 \mathrm{~A}: \quad$ mut häy käy veri-kokke-i-s ihan säännöllisestin

but HÄN go blood-test-PL-INE quite regularly

[ne lähete-tään,

they send-PAS

but she goes to blood tests regularly and they are sent

$8 \mathrm{~B}: \quad[$ niij just.

Yeah right

9 A: Rauma-l ain ja (.) kerrav vuade-s häy käy lääkäri-s. NAME-ALL always and once year-INE HÄN go doctor-INE to Rauma (to a central hospital) and once a year she sees a doctor. 
The speaker in excerpt (13) is one of the older women in my data who uses the pronoun hän a great deal: more than a third of the third-person pronoun references to a person are made with $h \ddot{a} n$ in her speech. Hän-references tend to coalesce in certain contexts and follow another hän referring to the same person. Some of the occurrences are possible to explain by a tendency towards standard language use in delicate situations, but not all. (Priiki 2016b.) When stories where the reference is mostly made with hän, are compared with stories where the typical pronoun is the demonstrative se, in the speech of people using hän extensively, a pattern can be detected. Stories with hän are told about people close to the speaker, the referent of hän is often the main character, the story is told from his or her viewpoint, and it is possible that the main character has originally told the story to the speaker. All these coalesce in example (13). When reference is made with se, the referent is usually someone the speaker does not know very well and the focus of the story is on observing the actions or the features of the main character, not on taking his or her viewpoint.

Comparison with the usages of the pronoun se is difficult, because in many of these cases the use of hän, in particular, creates the impression of semantic logophora or second hand information. However, I have tried to evaluate how common these functions of $h \ddot{a} n$ in the data are. There are 295 cases in which hän does not occur either in the canonical logophoric position (like in 3.1.) or as a subject of the verbs of speech act, cognition, emotion, or perception (as in 3.2.). Of these occurrences 57 cases (19\%) may be interpreted as semantic logophora, as in example (12) shown above. Cases such as example (13), where hän may express that the speaker has not witnessed the incident he or she is relating with his or her own eyes, are more common: there are 79 occurrences $(27 \%)$. Of the rest, 10 cases express uncertainty (cf. Laitinen 2005: 96-101), and the remaining 149 occurrences, may either be influenced by the use of $h \ddot{a} n$ in standard language, or the use of $h \ddot{a} n$ as a neutral third person pronoun in old southwestern dialects.

\section{Discussion and conclusions}

In this article, I have studied contemporary conversational data from the southwestern transition dialect area, where the logophoric pronoun hän has traditionally been used quite often outside the syntactic logophoric construction of indirect speech. As mentioned above, according to Laitinen (2005) and Nau (2006) semantic and discourse factors have 
more effect on the use of the Finnish logophoric hän than syntactic structure. I have approached the data by measuring the proportion of hän in different logophoric contexts.

In the conversations examined here, the syntactic logophoric construction seems to be the most stable context for the pronoun hän to occur. Even though some young speakers avoid the pronoun because it belongs to Standard Finnish and thus to formal language, in the prototypical construction of indirect speech, $97 \%$ of the third person pronouns referring to the original speaker are occurrences of hän. In the speech of many young and some middle-aged speakers, the syntactically logophoric position is the only context where they use hän, referring to a person not present, in the conversations recorded. As some of them use the demonstrative se even in the logophoric construction, I may conclude that in contemporary colloquial Finnish it does not predicate a different referent, because the referent is usually easily interpretable based on the contexts of the utterance.

Laitinen (2005: 82) speculates that hän might be disappearing from spoken language. It is impossible to contemplate, based on this data, whether there is a change occurring, or whether the pronoun hän is becoming strictly restricted to the structurally logophoric position in the southwestern transition dialect, as well as in some other Finnish dialects. Because older data sets have been collected according to the dialectological tradition and, therefore, consist of interviews with elderly people, it is unclear how the young people of that time used to talk, and whether they used the pronoun hän decades ago. There is evidence from a real time study that preferring the demonstrative pronoun se in references to people may be a feature belonging to a youth style, with the speakers starting to use hän when they get older (Lappalainen 2014). In this data, even though hän is not categorical in the speech of some young and middle-aged people, the occurrences of $s e$ in the structurally logophoric position are infrequent. Thus, I would not expect the logophoric hän to disappear from this dialect in the immediate future. It would be interesting to see whether people beginning to use $h \ddot{a} n$ in adulthood use it in a way that may be traced back to logophora or to the standard language.

In the southwestern transition dialect data examined here, the older speakers categorically use hän in a structurally logophoric position. In their speech, the canonic logophoric construction, however, does not predict the occurrences of $h \ddot{a} n$ very well, because some speakers also use hän quite extensively in main clauses (Priiki 2016b). Some of these 
occurrences are explainable through the broadening of the logophoric function when quoting thoughts, interpreting the referent's mental processes, relating narratives without using quoting phrases, and even expressing second hand information more generally. When quoting thoughts with the canonical logophoric construction, hän is not as usual as in speech quotations, but is still significantly more common than se. In addition to quoting thoughts, $h \ddot{a} n$ also seems to occur quite often in causative subordinate clauses expressing the cause of the referent's feeling. This means that many of the extended logophora phenomena noted by Laitinen (2005) are still actively used in contemporary conversations.

Another observation is that in conversational speech the canonical logophoric construction quoting thoughts seems to be quite rare. Instead of using the construction of indirect quotes, mental processes are simply told by describing them in the main clauses. However, the logophoric pronoun hän seems to expand into these main clauses, which creates the impression of logophoric context without quoting phrases (cf. Nau 2006). The relational frequency of hän in the main clauses mirrors the hierarchy presented by Stirling (1993: 259 and 1994: 2304), according to which logophoric pronouns are used primarily to transmit speech, and then, in this order, passing on another person's thoughts, cognition, feelings, and perceptions. In this data, as a subject of verbs expressing cognition, the relative frequency of $h a ̈ n$ is clearly higher than with other verbs. Hän is also statistically significantly more frequent as a subject of verbs expressing feelings; however, with perception verbs, the difference is not statistically significant. Interestingly, and in contrast with previous observations (Ylikahri 1996), hän in this data does not often occur as the subject of a speech act verb. With speech act verbs, as in reporting clauses, $h \ddot{a} n$ actually is statistically significantly less frequent than with other verbs. The reason for this correlation is most likely that when a speaker describes the speech act of another person, he or she is not interpreting the referent but just relating his or her own perception.

The older speakers, and those middle-aged speakers who use hän extensively, use it quite often to express the semantic logophora described by Laitinen (2005) and Nau (2006). It is, though, difficult to calculate how regularly hän is used in this function: if the logophoric pronoun itself creates the impression of second hand information, it cannot be reliably compared with similar occurrences of $s e$. For further study of the notion of semantic logophora, a quantitative analysis of 
tense ${ }^{5}$, for instance, and other deictic elements used in the utterance might prove helpful.

A summary of the observations made in this article is presented in Table 3. The syntactic logophora, i.e. the canonical construction of indirect speech explains $31 \%$ of the occurrences of $h \ddot{a} n$ in the data. Even though correlations were found in the data showing that verbs of cognition and emotion prefer hän as the subject pronoun, such verbs are so rarely used that the correlations do not predict the use of $h \ddot{a} n$ very well (cf. also Priiki 2016b). In addition, it was found that although the usages of expressing semantic logophora and second hand information with $h \ddot{a} n$ are more widely spread, as stated previously, the hän-occurrences in them are difficult to compare with the demonstrative se.

To answer one of my main research question, I may conclude, that together all the types of logophora explain more than half of the occurrences of hän. Most of the remaining occurrences can be interpreted as effects of standard language use. Older generation use non-logophoric $h \ddot{a} n$-pronouns more than younger people, but there are some non-logophoric occurrences in the speech of the young, too, especially when speaking to someone they do not know well (cf. Priiki 2016a).

Table 3. Occurrences of hän in the data and the proportion of different logophoric contexts.

\begin{tabular}{l|c} 
Function of logophoric $\boldsymbol{h} \ddot{\boldsymbol{a}} \boldsymbol{n}$ & $\mathbf{N}(\mathbf{\%}$ of the occurrences of $\boldsymbol{h} \ddot{\boldsymbol{a}} \boldsymbol{n})$ \\
\hline Canonical logophoric construction & $172(31 \%)$ \\
\hline A subject of cognition verb in main clause & $25(5 \%)$ \\
\hline A subject of emotion verb in main clause & $8(1 \%)$ \\
\hline Semantic logophora & $57(10 \%)$ \\
\hline Second hand information & $79(14 \%)$ \\
\hline Different types of logophora together & $\mathbf{3 4 1 ( 6 2 \% )}$ \\
\hline All occurrences of $\boldsymbol{h} \ddot{\boldsymbol{a}} \boldsymbol{( 5 4 8}$ & $\mathbf{5 4 0 0 )}$
\end{tabular}

Another research question is answered by concluding that, based on the analysis, the canonical indirect speech construction is the primary context for the logophoric hän-pronoun to occur, but semantic logophora is still an active function as well. Nau (2006) suggests that the structural

5 In Finnish, perfect and pluperfect tenses express second hand knowledge, and present tense creates an impression of a direct quote even without an introductory phrase (Helasvuo 1991, and Kuiri 1984). 
features are consequences of the nature of reported speech and, therefore, the semantic expression of second hand information would be the primary function. My interpretation of the quantitative analysis does not completely agree, as speakers who use hän very little use it only in structurally logophoric contexts. Therefore, I would consider the structural logophora a more salient function. In the speech of those who use $h \ddot{a} n$ more frequently, the pronoun hän expands from the canonical logophoric construction towards the semantic logophora. Moreover, the same speakers sometimes use hän as a neutral third person pronoun resembling the use in written Standard Finnish.

Methodologically, I hope to have shown that measuring frequency with statistics is a useful tool for exploring the saliency of different functions of a linguistic feature. Knowledge about frequency alone, however, is not a satisfactory conclusion as firstly, the reliable classification of the data, and secondly, the interpretation of the statistical results, require a careful qualitative analysis of the data.

\author{
Address \\ Katri Priiki \\ Finnish and Finno-Ugric Languages \\ 20014 University of Turku \\ Finland \\ E-mail: katri.priiki@utu.fi
}

\begin{abstract}
Abbreviations
ADJ - adjective suffix, ALL - allative, CL - clitic, CNJ - conjunction, CON - conditional, DEM - demonstrative pronoun, INE - inessive, INF infinitive, GEN - genitive, NEG - negation, PAS - passive voice, PCP participle, PL - plural, POSs - possessive suffix, PST - past tense, PTV partitive, $\mathrm{Q}$ - question suffix, SG - singular
\end{abstract}

\title{
References
}

Agresti, Alan (2002) Categorical data analysis. New York: Wiley.

Bhat, Darbhe Narayana Shankara (2004) Pronouns. Oxford University Press.

Culy, Christian (1997) "Logophoric pronouns and point of view". Linguistics 35, 845-859. 


\section{Katri Priiki}

Helasvuo, Marja-Liisa (1991) "Velipojalta kuultua: Kuinka aikamuodot jäsentävät kertomusta?” In Lea Laitinen, Pirkko Nuolijärvi, and Mirja Saari, eds. Leikkauspiste: Kirjoituksia kielestä ja ihmisestä, 77-86. Helsinki: Suomalaisen Kirjallisuuden Seura.

Herlin, Ilona (1998) Suomen kun. Helsinki: Suomalaisen Kirjallisuuden Seura.

Hyman, L. M. and B. Comrie (1981) "Logophoric reference in Gokana." Journal of African Languages and Linguistics, 3, 19-37.

Ikola, Osmo, Ulla Palomäki, and Anna-Kaisa Koitto (1989) Suomen murteiden lauseoppia ja tekstikielioppia. Helsinki: Suomalaisen Kirjallisuuden Seura.

ISK = Auli Hakulinen, Maria Vilkuna, Riitta Korhonen, Vesa Koivisto, Tarja Riitta Heinonen, and Irja Alho (2004) Iso suomen kielioppi. Helsinki: Suomalaisen Kirjallisuuden Seura. Available online at $<\mathrm{http}$ ://scripta.kotus.fi/visk $>$. Accessed on 03.06.2017.

Kallio, Jussi (1978) “Kolmannen persoonan dilemmat”. Sananjalka 20, 52-74.

Kuiri, Kaija (1984) Referointi Kainuun ja Pohjois-Karjalan murteissa. Helsinki: Suomalaisen Kirjallisuuden Seura.

Laitinen, Lea (2002) "From logophoric pronoun to discourse particle: a case study of Finnish and Saami”. In Ilse Wischer and Gabriele Diewald, eds. New reflections on grammaticalization, 327-344. Amsterdam: John Benjamins.

Laitinen, Lea (2005) "Hän, the third speech act pronoun in Finnish". In Ritva Laury, ed. Minimal reference: the use of pronouns in Finnish and Estonian discourse, 75-106. Helsinki: Finnish Literature Society.

Lappalainen, Hanna (2010) “Se ja hän puhutussa kielessä”. Kielikello (Helsinki) 4, 4-7. Lappalainen, Hanna (2014) "Idiolectal and generational changes in the light of real time data. The case study of 3rd person pronouns." Paper given in Sociolinguistic Symposium 20, Jyväskylä, 15th-18th June 2014.

Nau, Nicole (2006) "Out of Africa: logophoric pronouns and reported discourse in Finnish and High Latvian dialects”. Acta Linguistica Lithuanica 55, 55-87.

Nickel, Klaus Peter (1994) Samisk grammatik. Karasjok: Davvi Girji.

Nuolijärvi, Pirkko (1986) Kolmannen sukupolven kieli. Helsinkiin muuttaneiden suurten ikäluokkien eteläpohjalaisten ja pohjoissavolaisten kielellinen sopeutuminen. Helsinki: Suomalaisen Kirjallisuuden Seura.

Priiki, Katri (2011) Läsnäolo, tuttuus, tulkinta ja sävy. Ihmisviitteinen hän ja sen tehtävät Harjavallan, Kokemäen ja Huittisten nykypuhekielessä. Master's thesis, University of Turku.

Priiki, Katri (2014) "Kaakkois-Satakunnan henkilöviitteiset hän, se, tää ja toi subjekteina". Sananjalka 56, 86-107.

Priiki, Katri (2016a) "Henkilöviitteisten kolmaspersoonaisten pronominien vaihtelu keskustelukumppanin mukaan”. Puhe ja kieli 36, 2, 123-144.

Priiki, Katri (2016b) "Puhutun suomen kielioppia ja yksilöllistä vaihtelua. Kvantitatiivinen tutkimus $h \ddot{a} n$-pronominista Kaakkois-Satakunnan nykypuhekielessä". Sananjalka 58, 112-135.

Roncador, Manfred von (2006) "Logophoric pronouns". In Keith Brown, ed. Encyclopedia of language \& linguistics, 312-315. Amsterdam: Elsevier. 
Saukkonen, Pauli (1967) "Persoonapronominien hän : se, he : ne distinktiivi oppositio". Virittäjä 71, 286-291.

Setälä, E. N. (1883) Lauseopillisia havaintoja Koillis-Satakunnan kansankielestä. Suomi II: 16. Helsinki: Suomalaisen Kirjallisuuden Seura.

Seppänen, Eeva-Leena (1998) Läsnäolon pronominit: tämä, tuo, se ja hän viittaamassa keskustelun osallistujaan. Helsinki: Suomalaisen Kirjallisuuden Seura.

Siitonen, Kirsti (2008) "Sävypronomini hän”. Sananjalka 50, 87-109.

SMS = Suomen murteiden sanakirja. Helsinki: Kotimaisten kielten keskus. Available online at $<$ http://kaino.kotus.fi/sms $>$. Accessed on 29.02.2016.

Stirling, Lesley (1993) Switch-reference and discourse representation. Cambridge University Press.

Stirling, Lesley (1994) "Logophoricity and long-distance reflexives". In R.E. Asher and J. M. Y. Simpson, eds. The encyclopedia of language and linguistics, 2302-2306. Oxford: Pergamon Press.

Tagliamonte Sali A. (2009) "Be like: the new quotative of English". In Nikolas Coupland and Adam Jaworski, eds. The new sociolinguistics reader. Basingstoke and New York: Palgrave, Macmillan.

Vilppula, Matti (1989) "Havaintoja hän- ja he-pronominien käytöstä suomen murteissa”. Virittäjä 93, 389-400.

Ylikahri, Kristiina (1996) "Referoinnin laajentumat: hän-, he- ja se-, ne-pronominien käytöstä Siikaisten murteessa”. Virittäjä 100, 182-203.

Kokkuvõte. Katri Priiki: Soome keele logofooriline asesõna hän: kvantitatiivne lähenemine. Artikkel käsitleb asesõna hän 'tema, ta' logofoorilist kasutamist tänapäeva soome kõnekeeles. Logofooriline asesõna on vahend, mida kasutatakse vahendatud kõnes selleks, et viidata vahendatud lausungi algsele kõnelejale. Soome kõnekeeles kasutatakse asesõna hän enamasti logofooriliselt, kuigi standardkeeles on see regulaarne kolmanda isiku isikuline asesõna. Artikkel käsitleb asesõna hän logofoorilist funktsiooni sageduse vaatepunktist. Kvantitatiivsest analüüsist ilmneb, et kanooniline vahendatud kõnet väljendav konstruktsioon on asesõna hän kasutamise kõige püsivam kontekst, vaatamata sellele, et varasemates uuringutes on logofoori soome keeles peetud pigem semantiliseks kui struktuurseks. Prototüüpsest vahendatud kõne kontekstist on logofooriline kasutus levinud ka mujale: seda kasutatakse mõtete esitamisel, tunnete tõlgendamisel ja suhtluses osalejate rollide väljendamisel.

Võtmesõnad: logofoor, isikulised asesõnad, asesõnad, vahendatud kõne, kõnekeel, kolmas isik, soome keel 